Research Report

\title{
Identifying Dental and Oral Health Problems of Kindergarteners using KAFOGI Dental Photography
}

\author{
Muhammad Bima Rizki Dwitama, Nilna Naila Faiga, Nabilah Salim, Monika Amaria Putri Wijaya, Grahania \\ Octaviono Mahardika, Eris Basiroh, Pratiwi Nuzulil Hidayatillah, Amanda Brigitta Laksono, Nadiah Salsabila \\ Nosla, Mario Powa Mensana, Atika Hanani and R. Darmawan Setijanto \\ Departement Dental Public Health, \\ Faculty of Dental Medicine, Universitas Airlangga \\ Surabaya - Indonesia
}

\begin{abstract}
Background: Caries is one of the most common dental and oral health problems in preschool students. An epidemiological study reported that students of a kindergarten under Mojo Public Health Center coverage have a high caries index (def 6.9). The parental role, especially maternal role, significantly affects the child's dental and oral health. Children will also learn from the attitudes and behavior of their parents and close relatives. The preliminary epidemiological study also found that $72.7 \%$ of the mothers had higher knowledge levels, and $27.3 \%$ of the mothers had lower knowledge levels. The many behavioral theories that state that knowledge is one of the factors that influence a person in behavior. In the era of globalization, information dissemination is done quickly and easily with the help of several media. Purpose: An empowerment program was conducted to increase participants' knowledge levels using Dental Photo Card (KAFOGI). Method: This descriptive research involving 73 mothers from kindergarten. They were given pre-test before doing the programs. After viewing dental health education video, the mother were tested to place the image or photograph of teeth and placed to the right place in KAFOGI card. Results: As much as 78.1\% of respondents have answered correctly, while respondents who answered incorrectly were $21.9 \%$. Conclusion: With your knowledge of the number of child caries teeth, you will behave in accessing information about the child's oral health.
\end{abstract}

Keywords: Caries; Information Access Behavior; postcard.

Correspondence: R Darmawan Setijanto, Department of Dental Public Health, Faculty of Dental Medicine, Universitas Airlangga, Jl. Prof. Dr. Moestopo 47 Surabaya 60132 - Indonesia. E-mail: r-darmawan-s@fkg.unair.ac.id

\section{INTRODUCTION}

The preliminary epidemiological study found that $72.7 \%$ of the mothers had higher knowledge levels, and $27.3 \%$ of the mothers had lower knowledge levels. Many behavioral theories state that knowledge is one of the factors that influence a person's behavior.

In the era of globalization, information disseminates quickly and easily. Technological developments make this possible. Media has an important role in the learning process. Media can be used as a model to prevent ambiguity. Media can help simplify complex ideas for better delivery. The media can also represent unspoken information; even an abstractness of an idea can be exemplified using media. ${ }^{1}$ Printed media are visual media that is made through printing processes. Printed media delivers messages through printed letters and pictures representing an idea. A postcard is one of the printed media.
The Kartu Foto Gigi (KAFOGI) program addressed dental and oral health problems in children by empowering their mothers. Upon completion of the program, we, the PKL team expected that mothers would have increased knowledge levels about children's dental and oral health problems, would be aware of the importance of health, and would improve maternal behavior in accessing information. The program instrument was Kartu Foto Gigi, which translates to "Dental Photo Card". It was an A6-size postcard containing identity, photos, a total of decayed teeth, the severity of decayed teeth, and advice.

\section{MATERIALS AND METHODS}

The empowerment program was carried out by providing a dental photo card containing photos, identity, a total of decayed teeth, severity of decayed teeth, and advice. We 


\section{Indonesian Journal of Dental Medicine Volume 3 Issue 1 2020; 4-6}

then demonstrated how to calculate the total of decayed teeth using video. The total was then written on the postcard. The media of the program was a KAFOGI card and an instruction video hosted on YouTube.

DEF-T indices were calculated to know the decayed teeth of students of Nabawi Islamic Kindergarten, followed by playing the instruction video on how to count the total decayed teeth.

The educational video was uploaded under a YouTube account named Gigi Sehatku. The mothers of the kindergarteners were then instructed to watch the video before completing the KAFOGI card. The program took place on 20 October 2018 in Kebun Bibit, Surabaya.

\section{RESULTS}

The program was carried out in Kebun Bibit, involving 73 respondents who learned about the importance of dental and oral health using a video hosted on YouTube. The respective mothers then glued dental photographs of kindergarteners on the KAFOGI card.

Statistical analysis was then carried out by comparing the correct and incorrect answers to the total of decayed teeth. The results showed that $78.1 \%$ of the mothers had answered correctly, while the remaining $21.9 \%$ have failed in calculating the total of decayed teeth (Table 1).

Table 1. The results of the program

\begin{tabular}{lcc}
\hline & Total & Percentage \\
\hline Passed & 57 & $78.1 \%$ \\
Failed & 16 & $21.9 \%$ \\
\hline
\end{tabular}

\section{DISCUSSION}

Caries is still one of the most common dental and oral health problems in children and adults in Indonesian. ${ }^{2,3}$ Preschool students rely on their dental and oral hygiene to their parents, especially mothers. ${ }^{4}$ Growing teeth is an important milestone for a child. Parents, especially mothers, must have adequate knowledge on how to maintain dental and oral hygiene by teaching their children how to tooth brushing properly and correctly. ${ }^{5}$ Parents should pay attention to children's dental and oral health even though they are in the primary dentition period because the primary dentition will affect the secondary dentition. ${ }^{6}$ However, many parents downplay the importance of dental and oral health during primary dentition under the assumption that it will simply be replaced by the secondary dentition. ${ }^{7}$ Ten out of thirty parents of preschool students have incorrect assumptions about dental caries during primary dentition. They stated that deciduous teeth are temporary, and permanent teeth will replace them. Therefore, they assume that dental caries during primary dentition is not a big deal because deciduous teeth will eventually fall out and replaced by permanent teeth. Parental roles in assisting, caring, encouraging, and providing facilities related to child dental and oral health are essential. To habituate dental and oral hygiene in children, parents should be able to teach them patiently. ${ }^{8}$

Primary dentition significantly affects secondary dentition. Therefore, parental roles in assisting, caring, encouraging, and providing facilities related to children's dental and oral health are essential for maintaining their dental and oral hygiene. ${ }^{7}$ Dental health education must be introduced as early as possible, and parents should help to encourage and to teach their children about correct tooth brushing. ${ }^{9}$

The information about how to count the total of decayed teeth in children was delivered indirectly. Conveying information indirectly means delivering information to the target without having a face-to-face meeting but instead using media. The media of the empowerment program was a video hosted on YouTube. Visual media can facilitate the viewers to understand the information or messages contained in images. ${ }^{10}$ Also, audio media can stimulate the processes of thinking, feeling, ${ }^{11}$ attention, and ability of respondents to the material presented. ${ }^{12}$ Involving more senses means enabling us to process much more information. Experts reported that a $75 \%$ sense of sight and $13 \%$ sense of hearing result in a reasonably good stimulation for an optimal result. ${ }^{13}$ The factors above also influenced the program results in identifying dental and oral health problems using KAFOGI card.

\section{CONCLUSION}

The follow up plan included an evaluation to make the program more optimal. Also, the KAFOGI empowerment program was carried out indoor for a more conducive program. The empowerment program can be implemented in Surabaya or Indonesia in other areas, especially areas with similar problems.

\section{REFERENCES}

1. Sulistyani N, Jam J, Rahardjo D. Perbedaan Hasil Belajar Siswa Antara Menggunakan Media Pocket Book Dan Tanpa Pocket Book Pada Materi Kinematika Gerak Melingkar Kelas X. J Pendidik Fis Univ Sebel Maret. 2013;1(1):164-72.

2. B M, A C. 90 persen Anak SD di Bangka Sakit Gigi. Bandung: CV. Alfabeta; 2011.

3. Ningsih SU, Restuastuti T, Endriani R. Gambaran Pengetahuan dan Sikap Menyikat Gigi pada Siswa-Siswi dalam Mencegah Karies di SDN 005 Bukit Kapur Dumai. J Online Mhs Fak Kedokt. 2016;3(2):1-11.

4. Nindya Cahyaningrum A. Hubungan Perilaku Ibu Terhadap Kejadian Karies Gigi Pada Balita Di Paud Putra Sentosa Relationship of Mother Behavior Against Dental Caries Incidence in Toddler at Putra Sentosa Early Childhood. Dep Epidemiol Fak Kesehat Masy Univ Airlangga. 2017;5(April 2017):142-51.

5. Setiyawati R. Hubungan Kebiasaan Menggosok Gigi Sebelum Tidur Malam dengan Karies Pada Anak Usia 
Indonesian Journal of Dental Medicine Volume 3 Issue 1 2020; 4-6

Sekolah di Madrasah Ibtidaiyah Al-Istiqomah Tangerang. Univ Indones. 2012;10.

6. Dawani N, Afaq A, Bilal S. Oral health knowledge, attitude and practices amongst teachers of public school set-up of Karachi, Pakistan. J Dow Univ Heal Sci. 2013;7(1):15-9.

7. Gunawan S. Mewujudkan Kesejahteraan Bangsa: Menanggulangi Kemiskinan dengan Prinsip Pemberdayaan Masyarakat. Jakarta: Elex Media Komputindo; 2009. 141 p.

8. Budiharto. Pengantar Ilmu Perilaku Kesehatan dan Pendidikan Kesehatan Gigi. Jakarta: EGC; 2009. 110 p.

9. Abdul G. Buku Pintar Kesehatan Gigi dan Mulut. Yogyakarta: Mitra Buku; 2012. 166 p.
10. Cahya P. Unit Programmable Logic Controller (PLC) Sebagai Media Pembelajaran Pada Mata Pelajaran PLC. 2012 Jun 16;

11. Tangade PS, Jain M, Mathur A, Prasad S, Natashekara M. Conhecimento, atitudes e práticas frente à cárie dentária e prevenção da doença periodontal entre professores do ensino primário em Belgaum City, Índia. Pesqui Bras Odontopediatria Clin Integr. 2011;11(1):77-83.

12. Hamdani. Strategi Belajar Mengajar. Bandung: Pustaka Setia; 2011. 344 p.

13. Kapti REKO, Keperawatan FI, Magister P, Keperawatan I, Indonesia U. Efektifitas audiovisual. Rinik Eko Kapti, FIK UI, 2010. 2010; 